likely to be confirmed when large instruments are brought to bear upon the obieet frequently.

A Reported Occultation of Mars by Venus, A.D. 368, JULY 30.-Amongst the observations extracted from the Chinese Annals by the Jesuit missionary Gaubil, and printed in the Connaissance des Temps for 1810 , is one which is thus translated: "An $368=3^{\mathrm{e}}$ annce Tai-ho, $6^{2}$ lune, jour Kia-yn (3o juillet) Venus Éclipsa Mars." It may be worth while to examine how far M. Leverrier's tables will represent this reported observation. Calculating for July 30 at oh. and 8h. Paris mean time, we find the following quantities :-

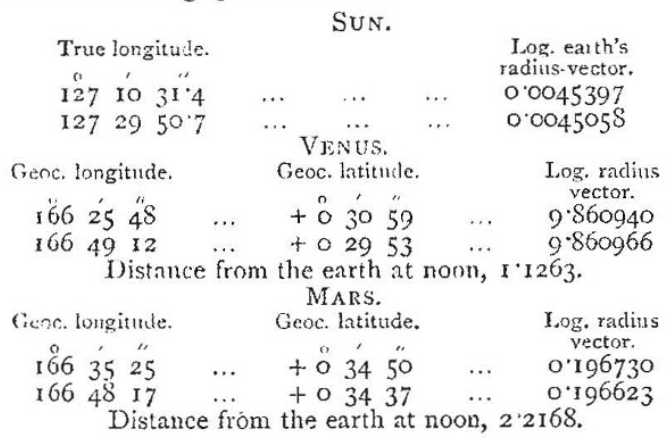

Hence the conjunction in longitude would occur July 30 at $7 \mathrm{~h} .18 .5 \mathrm{~m}$. Paris mean time, or July 30 at $15 \mathrm{~h} .4 \mathrm{~m}$. mean time at Nanking, where the Chinese Court was then established; Mars north of Venus $4^{\prime} 39^{\prime \prime}$. Consequently, according to $M$. Leverier's tables, there would be no occultation, but a very close approach, and considering the calculated time of conjunction, at an early hour in the morning, whereas the planets would be evening stars, it would appear that an occultation was only inferred from some previous or subsequent observations or both. The accuracy of the Chinese record, so far as regards a. near appulse of the two planets about the time named, is how. ever confirmed.

\section{THE PREHISTORIC STEPPES OF CENTKAL EUROPE}

I $\mathrm{N}$ a recent number of the Magdcburgische Zeitung is an interesting article by Dr. A. Nehring, upon the former extension of the steppes of Russia into Northern Germany. The country between Magdeburg and Halberstadt now belongs to one of the most fruitful and best cultivated districts in the Fatherland. Yet there are good grounds for believing that in former days this country was for a lengthened period a steppe-probably not an isolated steppe, but connected on the east with the great steppes of Russian Asia.

Northern Germany, including the country designated above, is generally regarded as having been in former times either overflowed by the sea and beset by icebergs, bringing down erratic blocks from the Scandinavian icemass, or, as Cæsar and Tacitus subsequently found it, covered with thick forests and extensive marshes. Both these views are correct-the one for what is usually called the Diluvial epoch-the other for the period immediately preceding historic times. Yet we may be allowed to ask what was the state of things in the intervening period? that is, after the sea had left the plains, and before the wood from the neighbouring heights bad grown over it. It is probable that the former sea-bottom, which made its appearance as a sandy plain saturated with salt, in many parts of North Germany became a steppe. The same thing has happened in other parts of the world.

A steppe need not necessarily be quite flat. Within the range of the extensive plains of the present steppes and prairies there are not unfrequently hills and undulating or elevated surfaces, and rocks breaking the uni- form level. The absence of wood is characteristic; the sandy surface is covered with grasses, dwarf herbs, and stunted bushes, which increase rapidly after the rainy season, but fade away altogether in the dry season, and present the appearance which we generally associate witir the word "steppe." The soil is not altogether unfruitful, for the sandy loam is much appreciated by many kinds of plants. It is only where the former sea-bottom consists of pure sand that herbage is altogether deficient. We designate as deserts such tracts of land-especially when they occur in hot countries. The soil of the "steppe" proper is often very fruitful, but its defect is that it has no regular supply of water, being only here and there varied by streams, marshes, and lakes, the latter generally salt. In the neighbourhood of such water a continuous vegetation may be developed, but the greater part of the steppe is covered with herbage for only a few months after the rains, and this disappears as quickly as it grows. Heat and cold, drought and flood, luxuriance and want succeed one another very rapidly.

The fauna of the steppe is, in its most obvious features, quite peculiar. Such of its animals as live on the ground and cannot escape the bad season of the year by emigration, become so accommodated to the climate and soil that they are never met with in other places-that is in woody or marshy districts. Among these the steppe-rodents (such as Jerboss, Sousliks, and Voles) are most remarkable. They find sufficient sustenance in the twigs, leaves, and berries of the steppe-plants. The dry sandy soil is well adapted for their underground dwellings, which protect them from the severe winter and from the attacks of the beast of prey. Let us take, for example, the steppes which lie between the Lower Volga and the Upper OD. The characteristic animals of this nistrict are (I) the large Jerboa (Aluctnga jaculus); (2) several species of Souslik (Spermophilus altaicns, \&c.); (3) the Steppe-marmot (Arctomys bobac); (4) the little Piping-hare (Lagomys presillus); (5) the Wild Ass (Equus onager); (6) the Saiga Antelope (Saiga tartarica). The remaining mammals met with, whether as resiclents or as temporary visitors, belong either to the fauna of Central Europe or to that of Northern Siberia.

Now this is exactly the same series of manmals which Dr. Nehring's continued researches in the stone quarries of Westeregeln (in the Circle of Manzleben) have brought to light. As regards the number of individuals the steppe-mammals show an undoubted predominance. The most numerous are the Jerboas and the Sousliks, which must formerly have inhabited the neighbourhood of Westeregeln in large numbers. Nearly quite as numerous must have been the wild asses, of which the teeth and bones occur in large masses. There are also many remains of Voles, mostly of such species as at the present time are only found in Eastern Europe and Western Asia. Of the marmot and piping-hare Dr. Nehring has at present only single examples, but expects to find more as his excavations continue.

Of the characteristic steppe-mammals mentioned above the Saiga is the only one not yet found at Westeregeln. But it is to be expected that it will yet be discovered there, because the whole facies of the extinct fauna indicates its former presence, and the Saiga has already been found fossil in several places further to the west. Perhaps also a specimen of a supposed large sheep (U $7 /$ is), which was obtained some years ago near Westeregeln, may really have belonged to the Saiga.

On the whole, if we put the Saiga aside, the Diluvial fauna of Westeregeln seems manifestly to have been a steppe-fauna, and brings us to the conclusion that the district in which these animals dwelt must have been a steppe of similar character to that which now extends between the Volga and the $\mathrm{Ob}$, and perhaps have been even in direct connection with it. That the animals, the remains of which are found in the Diluvium of Weste- 
regeln, actually lived on the plains undex the Harz, Dr. Nehring has proved satisfactorily by his own researches. It follows that this country must have formed a steppe during a certain portion of the Diluvial period.

If the above conclusions are right it follows that in a former epoch those parts of Central Europe which were formerly covered by the sea generally became steppes before coming into their present condition. Perhaps the Magdeburg-Halberstadt steppe extended southwards over Aschersleben and Halle into the valley of the White Elster, for Prof. Liebe has found, near Gera, fossil remains of several specimens of the large Jerboa, as also of the Souslik and other animals which have been obtained at Westeregeln. Besides, remains of the same animals, as well as those of the Saiga antelope and wild ass, have been found at several other points to the west. It follows, therefore, that the steppe must have extended considerably in that direction.

The result of these investigations is the more important as manifest traces seem to show that at the Steppe period man had already occupied the plains of middle Europe, and occasionally took up his abode even on the ancient steppe of Westeregeln.

The cause of the disappearance of the ancient steppes of Cer.tral Europe Dr. Nehring supposes to have been the gradual increase of the forests which advanced along with the change of climate. In the Steppe period England and Scandinavia were still joined to the continent of Europe, the North Sea and the East Sea did not exist in their present extent, the Gulf Stream had a more northern direction, and the climate was drier and more severe than it now is. As the climate softened and the forests advanced from the wooded hills, the steppe animals gradually withdrew themselves towards the east, and disappeared, leaving only fossil remains to attest their former abundance.

\section{THE COLORADO BEETLE}

$\mathrm{W}$ E have already several times referred to this destructive insect, and now that it has reached Europe we give an illustration of the creature in its various conditions, along with some notes which have been forwarded to us by Mr. Andrew Murray. The Board of Trade have reissued the circular, with a coloured illustration, referred to in our article on Our Insect Foes, vol. xv., p. 85 .

The Colorado beetle belongs to that subdivision of vegetable-feeding species known as Phytophaga. It may help the general reader to an appreciation of their place and character if we mention the Turnip flea as a British species of this section, and still nearer to it those brilliant green little gems that are to be seen in quantity on the leaves of the white nettle (Lamium album) in summer, and which in Scotland bear the colloquial name of Virgin Maries, an appellation, however, which is also there sometimes indifferently given to the ladybird. The genus in this great section to which these little insects equally with the Colorado beetle belong is named Chrysomela. It is true that its first describer, Say, named it Doryphora decemlineata, and that at first that designation acquired such extensive currency that it was all but universally adopted ; and many people from old habit or deference to general usage, even when they know it to be an error, stil use it ; but all entomologists know that it is not a Doryphora, but a portion of the great genus Chrysomela, without going into other details. The difference between them can be very easily pointed out by one single character. Doryphora is a massive Chrysomela with a strong spike projecting forwards from the middle (the mesosternum) of the under side, while Chrysomela has no such spike. The former is a genus peculiar to the South American region, including Central America, and contains the largest, finest, and most beautiful species of the family. Some of them are somewhat similarly

marked to the Colorado beetle, which no doubt led to Say mistaking the genus. But although the Colorado species and its allies are clearly enough Chrysomela, systematists in arranging that genus have broken it up into several 'sub-genera or new genera, and the latest authority (Chapuis) has placed them in a genus named Leptinotarsa, but at the same time indicates his opinion that a further subdivision must take place, which will leave the Colorado beetle and its relations in a sub-genus by themselves, as was long ago ( 1837 ) proposed by M. Chevrolat, under the name of Polygramma. For the characters of these subdivisions we refer to M. Chapuis's genera, and for the specific characters of the species falling under Polygramma to Stahl's diagnosis and Mr. Riley's first

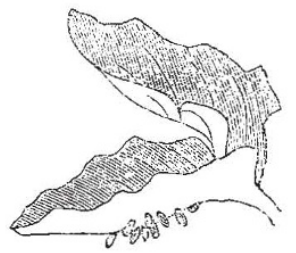

Potato leaf with eggs of Colorado Beetle on under side.

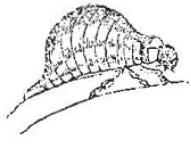

Larva of Colorado Beptle: natiuzal size. -Note. The double row of lack spots along the abiomen is not sufficiently distinct in this cut.

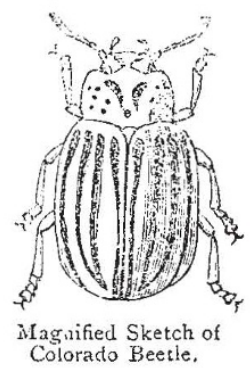

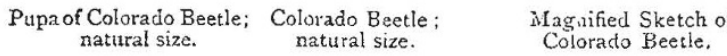

Missouri Report (1869). These are, first, the true Polygramma (Decemlineata, Say) that has occasioned all this alarm, which is the most northerly species, its native home being the eastern base of the Rocky Mountains and the prairies extending eastward. Next a variety called Multilineata by Walsh and Stahl, but which is not specifically distinct. Then a good species, Polysramma juncta, which ranges through the Confederate States of North America, and is easily recognised by two of the dorsal black lines uniting to make one thicker one. Farther to the south, about Vera Cruz and Costa Rica, \&c., there is another species very like the Colorado species, called Polygramma undecemlineata, Stahl, and which is found in enormous numbers in these parts of Mexico. Lastly Stahl records another, which we have not seen, from Mexico, under the name of novemlineata. All these feed on different plants, although probably plants all belonging to the same order, the Solanaceæ.

\section{NOTES}

THE Society of Arts has awarded its Albert Medal "for distinguished merit in promoting Arts, Manufactures, or Commerce, to Jean Baptiste Dumas, member of the Institute of France, the distinguished chemist, whose researches have exercised a very material influence on the advancement of the Industrial Arts." The Society's Medals for papers read during the session, have been awarded to Prof. Barf, M. A, for his paper on "The Treatment of Iron for the Prevention of Corrosion;" J. Meyerstein, for his paper on "Stenochromy, a Novel Method of Printing in Colours ;" A. J. Ellis, F.R.S., for his paper on "The Measurement and Settlement of Musical Pitch ;" B. St. John Ackers, for his paper entitled "Deaf not Dumb ;" Commander Cameron, R.N., 